\section{樹木形態形成の重力による制御}

\section{1. はじめに}

海から陸へと上陸した植物は、地上環境に適応し て何百年も生きのびて、地上最大最長命を誇る生物、 すなわち樹木へと進化をとげた。

一方人類は、弚の進化の過程で樹木を樣々な目的 に利用することにより、关の生存を可能とし更に生 活を豊かなものとしてきた。

樹木の二次木部 (木材) こ光は、地球重力に逆らっ て巨大な樹体を持ち上げて、上方へと成長させるこ とのできる組織、すなわち支持組織である。樹木が 風や遺伝病 (しだれ性等) のために傾くと、弚のよ うな傾斜刺激により、あるいは外生の植物ホルモン 等により誘導される特殊な二次木部である、あて材 により姿勢制御が行なわれる。あて材形成に関して は、筆者らによる、シダレザクラの枝におけるジべ レリン投与による引張あて材誘導の研究をも含めて、 前著においてすでに紹介がなされた (中村、吉田 2000)。

一方草本植物に関しては、 山下雅道氏が考案された疑似 微小重力環境作出装置である 三次元クライノスタット (山 下ら 1997）を用いて、重力形 態形成に関する実験が行なわ れ、弚の結果が宇宙実験によ り支持されてきた（保尊ら 1997、2000、高橋ら 2000)。こ のようにして「自発形態形成」 や「ネガティブコントロール」 等の発芽時幼植物の重力形態 形成に関する貴重な知識をえ ることができた。

草本植物に関してえられた 重力形態形成についての研究 成果に興味をもち、成長に要 する時間や空間が草本植物に 比べると莫大ではあるが、あ えてサクラ幼植物を三次元ク ライノスタット上の疑似微小 重力下で培養して地上予備実
表 1 地上と微小重力下における樹木の茎の発達比較

\begin{tabular}{|c|c|c|c|c|c|c|c|}
\hline & \multirow[b]{2}{*}{ 茎成長方向 } & \multirow[b]{2}{*}{ 茎肥大方向 } & \multirow[b]{2}{*}{ 木部幅 } & \multicolumn{3}{|c|}{ 二次木部纖維細胞 } & \multirow[t]{2}{*}{ 二次師部勒皮纎維 } \\
\hline & & & & 分裂活性 & $\underset{\text { 細胞壁 }}{\Sigma}$ & $\begin{array}{l}\text { セルロー } \\
\text { ロフィフ } \\
\text { 傾角 } \\
\end{array}$ & \\
\hline 地上 & $\begin{array}{l}\text { 重力と平行 } \\
\text { (通直性) }\end{array}$ & $\begin{array}{c}\text { 重力と垂直 } \\
\text { (真円性) }\end{array}$ & 大 & 高い & 発達 & 小 & 発達 \\
\hline 微小重力下 & $\begin{array}{c}\text { 不揃い } \\
\text { 通直性喪失) }\end{array}$ & $\begin{array}{c}\text { 不定 } \\
\text { (真円性喪失) }\end{array}$ & 小 & 低い & 発達不全 & 大 & 発達不全 \\
\hline
\end{tabular}
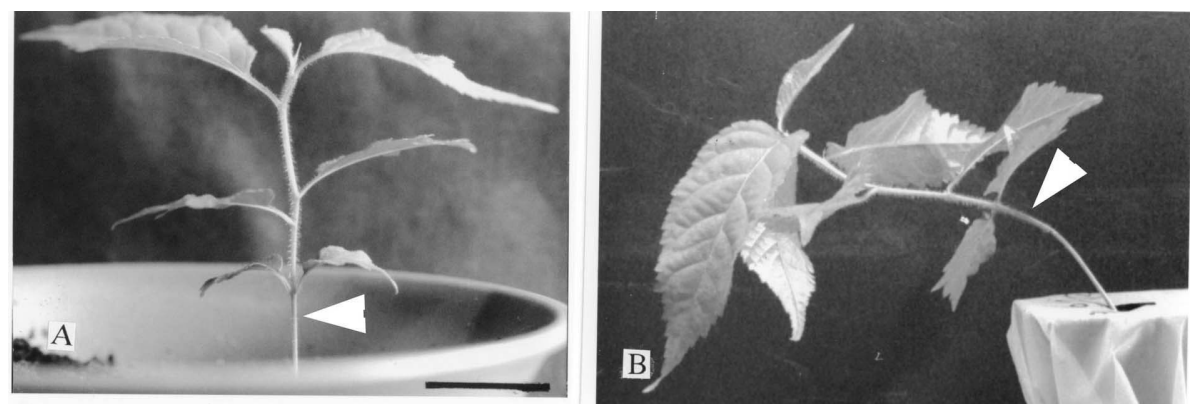

图 14 週齢の三次元クライノスタット上ヤマザクラ幼植物 A：地上対照、B : 三次 元クライノスタット上植物 矢印: 基部節間 (伸長成長完了、二次肥大成長中節間) バー : 60mm (Adv. Space Res., 27(5), 957-960, 2001 より一部改変転載) 


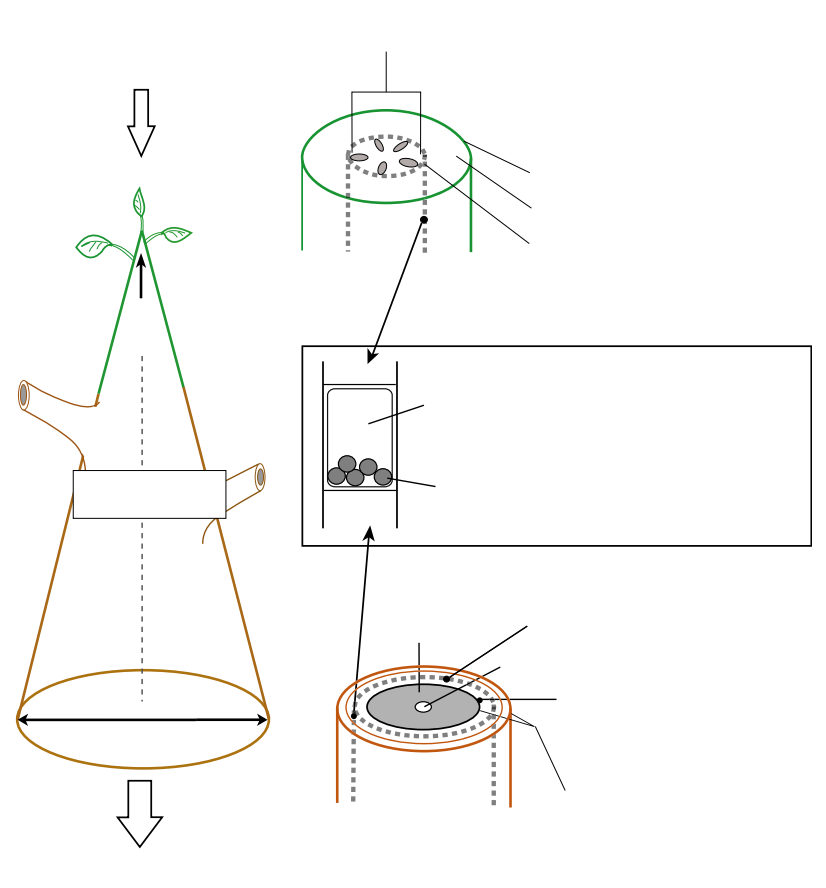

图 2 樹木の成長、組織及び沈降性アミロプラス卜(第18 回宇宙利用シンポジウム、18、184-187、2002より一部改 変転載)

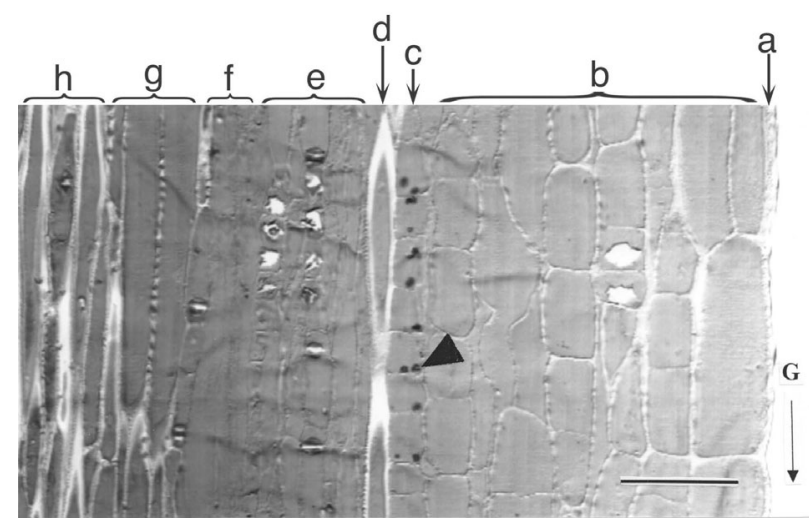

図 3 共焦点レーザー走査顕微鏡透過型イメージ画像 矢 印: 沈降性アミロプラスト G: 重力の方向、a: 表皮、b: 皮層、C: デンプン鞘細胞 (内皮)、d: じん皮繊維、 $\mathrm{e}$ : 二次 師部柔細胞、f: 形成層、g: 道管、 $\mathrm{h}$ : 二次木部繊維細胞 (図 1 と同じく一部改変転載)
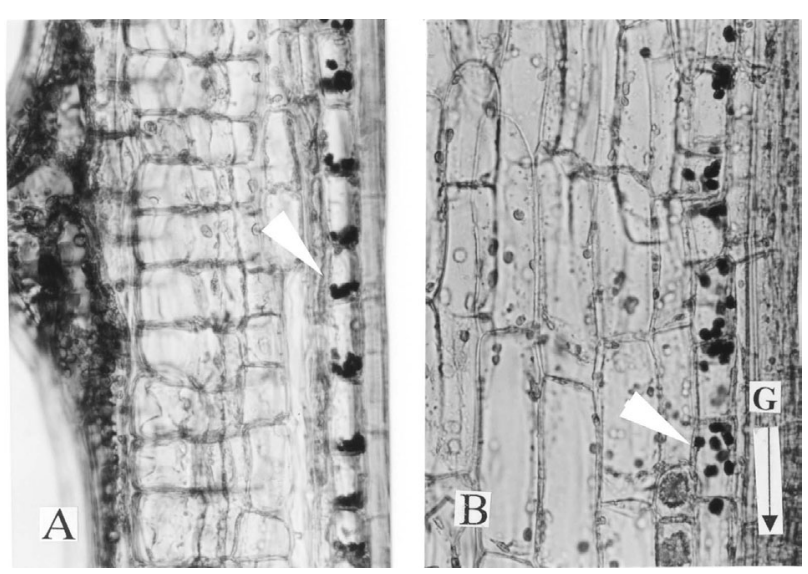

图 4 内皮デンプン鞘細胞中の沈降性アミロプラスト 矢 印：IKI染色による同アミロプラスト

$A$ : 地上対照、B : 三次元クライノスタット上植物 (図1と 同じく一部改変転載)

く認められた。このような結果は、二次木部の形態 形成が地球重力により制御されており、光の結果と して、光の組織の同心円状配列からなる茎が、上方 へとまっすぐに成長することを可能としていると考 えられる (図 1A)。一方疑似微小重力環境下では地 上対照でみられるような通直性の喪失 (図 1B)、す なわち伸長方向の定まらない茎の成長、および茎横 断面の真円性の喪失がひきおこされたと考えられる。

\section{2 微小重力下の茎における沈降性アミロプラスト の分散}

樹木の地上対照植物の基部節間においても、草本 植物の場合と同樣の、重力センサーである内皮デン プン鞘細胞中の沈降性アミロプラストの存在を確認 した (図 2、3および4A)。内皮デンプン鞘細胞中に は数個の直径約 $4-6 \mu$ mの沈降性アミロプラスト が存在しており、このアミロプラストは大きなデン プン粒を 2 - 3 個含みラメラ構造をも有しているこ とが明かとなった。一方、三次元クライノスタット 上の同節間においては、図4Bに示すように、アミロ プラストは細胞中に分散していた。
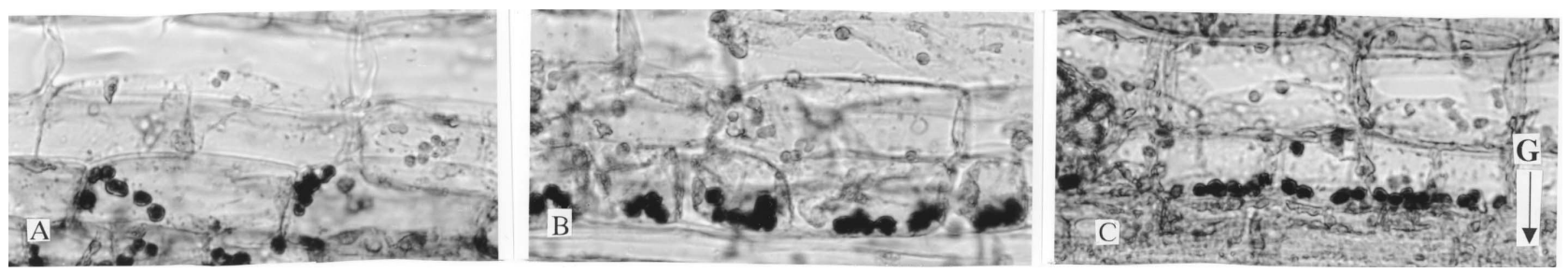

图 5 図 $1 \mathrm{~A}$ の植物を、垂直位から水平位に置換した時の沈降性アミロプラストの挙動 $A ： 2$ 分後 $B: 10$ 分後 $C: 60$ 分後 (図 1 と同じく一部改変転載) 


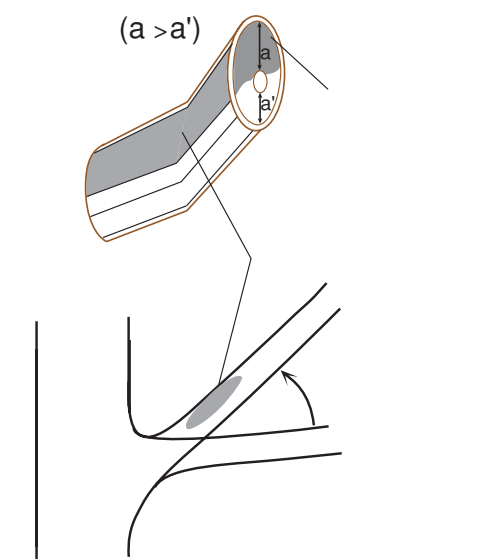

伸長停止·肥大成長部位の

偏心成長による重力屈性 $\left(b<b^{\prime}\right)$
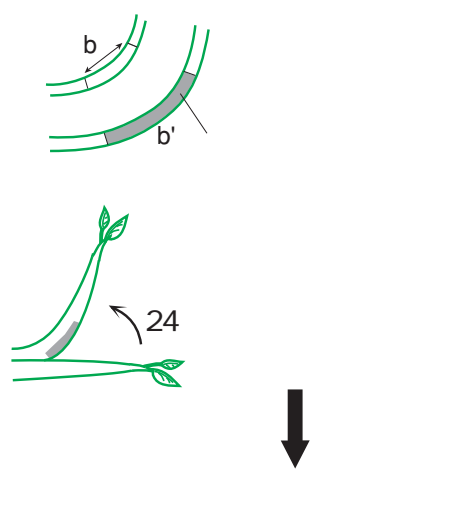

伸長帯の偏差成長による重力屈性

图 6 樹木の重力応答 (図 2 と同じく一部改変転載)

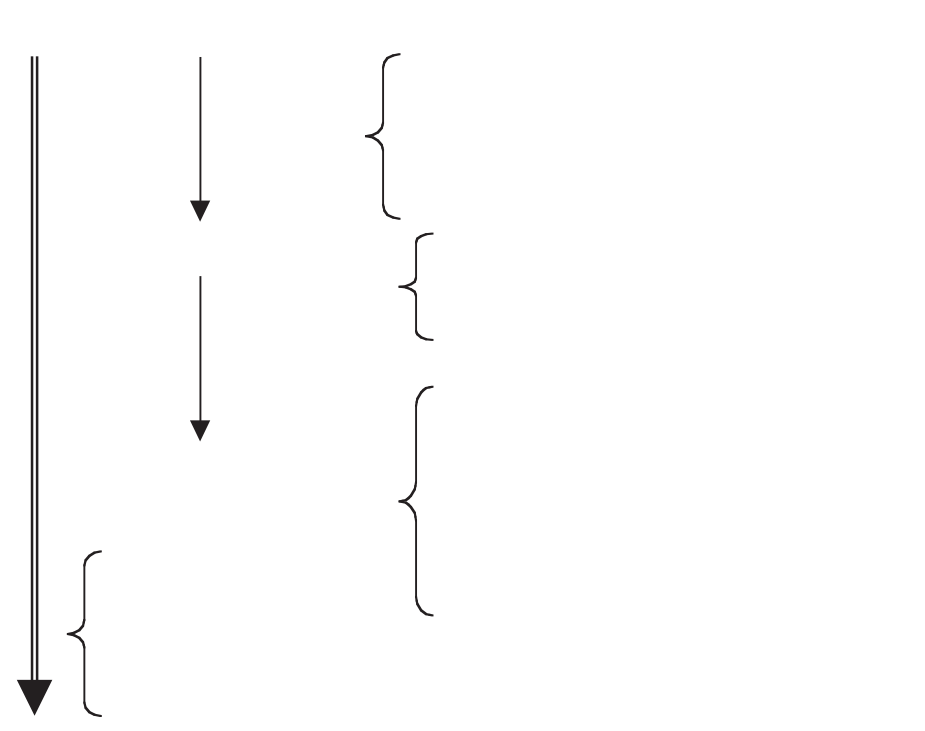

表 2 樹木の重力応答

図 5 に示すように(Nakamuraら 2001)、地上対照の 植物を垂直位から水平位に置換すると、沈降性アミ ロプラストの垂直方向への再沈降が行なわれた。ま た幼植物にサイトカラシンDやEGTA を処理するこ とにより、沈降性アミロプラストの移動が阻害され ると同時に、負の重力屈性が阻害されることが観察 された。このような結果は、草本植物の場合と同樣 に、重力刺激伝達に細胞骨格およびイオンチャネル 等が関与している可能性を示していると考えられる。

これらの結果により、草本植物の伸長成長におけ ると同樣に、樹木二次木部の肥大成長においても、 沈降性アミロプラストが重力センサーとして機能す る可能性が示唆された (菅野ら 2001、中村ら 2002)。

そして、オーキシンやジベレリンの関与の 可能性も示されてはいるものの、刺激の伝 達に関しては今後の研究を必要とする。

重力感受については表2に示すように、草 本植物と同樣の機構の存在が示されたが、 一方実際に生体反応が引き起こされるまで の反応時間は草本植物に比べて樹木におい ては著しく長い時間を必要とする。これは 重力刺激が形成層始原細胞の分裂活性を高 め、さらに木部および師部母細胞の分裂を うながし、光の結果として組織が発達して 重力に反応した茎の成長がもたらされる時 間が長いことに起因していると考えられる。

いずれにしても、草本植物と木本植物で は重力刺激感受の仕組みは似ているが、光 の生体反応が著しく異なることを示すものであ る (図6)。

\section{3.おわりに}

このようにして、樹木の支持機能をになう二 次木部の発達が、草本植物と同樣の重力セン サーにより感受された地球重力により制御され ていることがあきらかとなった。重力感受に関 わる遺伝子については、すでに草本植物におい てみいだされているSCR 遺伝子が、同樣に機能 している可能性がある (Sassaら 2002、森田ら 2002)。

草本植物における、一次組織の表皮細胞や皮 層細胞による偏差成長とは異なり、樹木の二次 木部の傾いた茎の上側と下側の肥大成長の違い により生ずる偏心成長による生体反応のメカニズム については、さらに詳しく検討される必要がある。 樹木においては、重力刺激を感受して二次木部が発 達し、姿勢制御をするまでには、数日から 1力月近 い時間を要し、光の重力屈性は草本植物の数時間後 には明確になる重力屈性とは著しく異なるものであ る。

樹木形態形成の重力による制御のさらに詳しい研 究のためには、是非とも宇宙実験が必要である。

\section{引用文献}

Hoson, T., Kamisaka, S., Masuda, Y., Yamashita, M. and Buchen, B. (1997) Evaluation of the three-dimensional clinostat as a simulator of weightlessness. Planta, 203, S187-S197. 
Hoson, T. et al. (2000) Growth regulation mechanism in higher plants under microgravity conditions. Biol. Sci. Space, 14(2), 75-96.

森田 (寺尾) 美代、田坂晶生 (2002) 植物はどのようにし て重力方向を知るのか. 蛋白質 核酸 酵素,(47)12, 1690-1694.

Nakamura,T., Sassa, N., Kuroiwa, E., Negishi,Y., Hashimoto, A., Yamashita, M. and Yamada, M. (1999) Growth of Prunus tree stems under simulated microgravity conditions. Adv. Space Res., 23(12), 2017-2020.

中村輝子、吉田正人 (2000) 樹木と重力. 宇宙生物科学, 14(3), 123-131.

Nakamura, T., Negishi, Y., Funada, R., and Yamada, M. (2001) Sedimentable amyloplasts in starch sheath cells of woody stems of Japanese cherry. Adv. Space Res., 27(5), 957-960.

中村輝子、根岸容子、菅野真実、船田良、山田晃弘 (2002) サクラの重カセンサーについて.第18回宇宙利用シン ポジウム, 18, 184-187.

Sassa, N., Matsushita, Y. Nakamura, T. and Nyunoya, H.(2001) Molecular characterization and in situ expression pattern of pea SCARECROW gene. Plant and Cell Physiol., 42(4), 385394.

菅野真実、根岸容子、福田幸子、本多珠巳、山田晃弘、中 村輝子 (2001) ヤマザクラの茎の肥大成長部位におけ る沈降性アミロプラスト.宇宙生物科学, 15(3), 256-257.

Takahashi, H., Kamada, M., Yamazaki,Y., Fujii,N., Higashitani, A., Aizawa, S., Yoshizaki,I., Kamigaichi, S., Mukai, C., Shimizu, T., Fukui, K. (2000) Morphogenesis in cucumber seedlings is negatively controlled by gravity. Planta, 210, 515518.

山下雅道、山下明子、山田晃弘 (1997) 3 D -クライノス タットと炎の動作特性. 宇宙生物科学, 11(2), 112-118.

なかむらてるこ

日本女子大学理学部物質生物科学科 大学院理学研究科

干 112-8681 東京都文京区目白台 2-8-1

E-Mail: teruko-n@fc.jwu.ac.jp 


\title{
Control of Morphogenesis of Woody Plant by Gravity on Earth
}

\section{Teruko Nakamura}

Faculty of Science, Japan Women's University, 2-8-1, Mejirodai, Bunkyo-ku, Tokyo 112-8681, Japan

\begin{abstract}
Using the weeping branch of Japanese flowering cherry tree and its woody stem of the seedling grown under simulated microgravity condition by three dimensional clinostat, it was elucidated that the morphogenesis of its secondary xylem supporting the plant itself to grow upward is seriously controlled by gravity on earth with a sedimentable amyloplast as its sensor. Space experiment of woody plant is expected to elucidate such problem.
\end{abstract}

Keywords: earth, gravity, morphogenesis, secondary xylem, woody stem 